DIGITAL COMMONS
@ UNIVERSITY OF SOUTH FLORIDA

Volume 2

Issue 2 Volume 2.2 (Fall 2012): Open Access

\section{ABO: Interactive Journal for Women in the Arts, 1640-1830}

2012

\title{
Intersectionality of Race, Gender, and Class in the 'Hard Times: Women Scholars and the Dynamics of Economic Recession'
}

\author{
Christine Clark-Evans \\ Pennsylvania State University, cxc22@psu.edu
}

Follow this and additional works at: https://digitalcommons.usf.edu/abo

Part of the Dramatic Literature, Criticism and Theory Commons, Educational Methods Commons, Feminist, Gender, and Sexuality Studies Commons, and the Literature in English, British Isles Commons

\section{Recommended Citation}

Clark-Evans, Christine (2012) "Intersectionality of Race, Gender, and Class in the 'Hard Times: Women Scholars and the Dynamics of Economic Recession'," ABO: Interactive Journal for Women in the Arts, 1640-1830: Vol.2: Iss.2, Article 2.

http://dx.doi.org/10.5038/2157-7129.2.2.2

Available at: https://digitalcommons.usf.edu/abo/vol2/iss2/2

This Scholarship is brought to you for free and open access by Digital Commons @ University of South Florida. It has been accepted for inclusion in ABO: Interactive Journal for Women in the Arts, 1640-1830 by an authorized administrator of Digital Commons @ University of South Florida. For more information, please contact digitalcommons@usf.edu. 
Intersectionality of Race, Gender, and Class in the 'Hard Times: Women Scholars and the Dynamics of Economic Recession'

\section{Keywords}

class, economic recession, gender, higher education, intersectionality, race, state of the profession, women scholars of color

\section{Creative Commons License}

(c) $($ ) $\Theta$

This work is licensed under a Creative Commons Attribution-No Derivative Works 3.0 License. 
For the 2012 American Society for Eighteenth-Century Studies meeting in San Antonio, Texas, when the Women's Caucus had decided collectively the topics for our eighteenthcentury research panel and the professional interest panel, as is our tradition, Miriam L. Wallace suggested that Linda Zionowski (English, Ohio University) and I (French and Francophone Studies, Women's Studies, and African American Studies, Pennsylvania State University) submit a combined title and panel proposal. This is an account of the roundtable and my perspective on intellectual and ethical questions of race, gender, and class in local settings and the wider context.

Linda and I had quickly decided to be co-chairs, and renamed the panel, "Hard Times: Women Scholars and the Dynamics of Economic Recession." The panelists were pitch perfect for a discussion of a feminist theoretical frame surrounding the crushing effect of the economic recession on women, especially women scholars in the midst of historic economic collapse: Julie C. Hayes (University of Massachusetts Amherst); Catherine Ingrassia (Virginia Commonwealth University), and Cynthia J. Klekar, (Western Michigan University).

The subjects of their presentations ranged from the de-professionalization of faculty labor, the need to constantly defend the humanities as important, the hard road to become a full professor, an administrator, and a college or university president, mentoring graduate students, and intellectually engaging undergraduate students. The 30 or so ASECS members in attendance, more women than men, responded immediately with their own narratives about hiring, funding, tenure, and promotion, bald-faced insults, and stagnating salaries.

Toward the end, I talked about hard times for women scholars of color in the U.S. and the close relationship between education and citizenship. On the macro level, women scholars lost money, assets, and opportunity as a result of the economic recession that had begun in the last fifteen years and deepened severely after 2008. New women PhDs and assistant professors are now too often subject to the "last-hired, first-fired" rule, departmental budget cuts, larger classes to teach, fewer choices in seminars, fewer publication venues for their research, less administrative support staff, and reduced tenure and promotion rates. Adjuncts, post-doctoral appointees, and part-time faculty fear for their job security. All women struggle to have and keep their families.

On the micro level, employment for women scholars has even fluctuated from term to term, and some positions are being completely eliminated. Women associate professors have fewer prospects for promotion to full professor or lateral transfers and have taken hard hits in their pension, health, and retirement plans. Full professors have almost no prospects for hiring outside of their institutions, teach fewer graduate seminars, and have received little or no pay increases. At each rank and category, women scholars are vulnerable to the domino effect, when budget cuts are compounded with union busting tactics by administrators and trustees. Programs and units of special interest to women scholars and academic units that are progressive in their approach and encourage critical analysis and creative problem solving are often subject to attacks against the humanities in general. Cuts to smaller or newer academic programs that develop consciousness of 
social responsibility, justice, and equality, especially those instituted since the 1990s, develop into a convenient pattern of striking at the legitimacy of women's studies and related disciplines, which are usually only researched and offered in the curriculum by women professors.

But there are also profound changes at the intersection of race, gender, and class for women of color in higher education, changes that have escaped notice but deserve theoretical and social consideration. Patricia Hill Collins in Black Feminist Thought: Knowledge, Consciousness and the Politics of Empowerment, $2^{\text {nd }}$ ed. (New York, London: Routledge, 2000, 18) traces the epistemological paradigms and the politics of Black feminist thought from Maria Stewart to Kimberle Crenshaw. She explains how African American women have been denied their democratic and human rights and how their intellectual work has been suppressed under the weight of multiple oppressions. Collins writes about the political, economic, and social conditions of African American women in the U.S. and the appropriation from them of what Simone de Beauvoir calls women's productive and reproductive labors in The Second Sex, trans. Constance Borde and Sheila Malovany-Chevalier (New York: Alfred A. Knopf, 2010, 72). Writing about the seventeenth and eighteenth centuries, the historian Jennifer L. Morgan exposes the grueling social processes and hardships of work and childbearing for enslaved women in Laboring Women: Reproduction and Gender in New World Slavery (Philadelphia: University of Pennsylvania Press, 2004, 144).

Instead of living in an agricultural society under a system of racial slavery, women scholars of color today are in a rich, post-industrialized society under an institutionalized system of racial, sexual, and class hierarchy and oppression. In this social context, the close connection between education and citizenship and the exclusion or suppression of women scholars of color are evident in relation to their professors, administrators, fellow and sister students, and staff in colleges and universities. Ever since the 1954 Supreme Court decision declared that separate, racially segregated education is unequal, the place and role of African American students and eventually all of the protected class of students of color, women, other-religious, and the disabled became contended as they entered institutions of higher education. Women scholars of color enrolled in colleges and universities in increasing numbers, but with the current economic crisis the gains made since Brown v. the Board of Education of Topeka have contracted sharply in their number, educational level, and academic and professional ranks in predominantly white colleges and universities. Alternatively, there has been little expansion of historically Black colleges and universities. Since the Brown decision, there still have been very few newly minted Ph.D.s of color to graduate in philosophy and mathematics for example, especially African Americans.

The percentage of undergraduate students of color in the humanities have dwindled and practically disappeared from many programs in public and private institutions even before 2008. Like their majority white counterparts, because higher education has increased in cost in the last decades, high achieving and financially able women and men undergraduates of color redirected their efforts away from the private and public IvyLeague institutions to attend public colleges and universities. 
While graduating from college was already difficult, since the mid 1990s it became more difficult for women and men undergraduates of color. After the present economic recession hit communities of color earlier and harder than the rest of the population, the pipeline of women and men students of color alike, going from high school, college, and graduate school to professorial and administrative ranks, has been broken. The intersection of race, gender, and class for women students of color in higher education drastically reduced their numbers, narrowed their intellectual and professional opportunities, and stopped their advancement to senior faculty and upper administrative levels.

Compared to the majority of their peers, the number of qualified women students of color was already falling, and because of the economic crisis, they are fewer in certain classrooms, disciplines, faculties, and administrative positions and have almost disappeared from graduation rolls. However, in an effort to conceive and share strategies for survival, at the end of the ASECS Women's Caucus professional roundtable, we invited women scholars as well as male colleagues, at various stages in their careers to speak not only to the broad set of these intellectual and professional questions in academia but also about the situation of women scholars of color.

My suggestion was that in principle all of the scholars in the room who identified with any race, color, ethnicity, or religion, whether women or men, were capable of having an impact on women scholars of color. There are many ways to teach and advise them: recruiting undergraduates in the humanities and especially around areas of shared interest, whether related to race, gender, and class or topics involving other intellectual and ethical questions; mentoring them by finding out their interests and suggesting projects in which they could learn more by giving the professor assistance in appropriate tasks involved in research and teaching like research assistant, lab or project assistant; reading or experimental group participant/assistant; timely announcements of lectures, conferences, speakers, and programs that would interest them on and off campus; offering a few credits for doing bibliographic research; work-study and unpaid assistance to the professor, not involving confidentiality or peer grading; directing their teaching or tutoring assistance to lower level students; short term study projects for the student's enrichment or extra-credit where appropriate; assistance in forming or joining a peer study group; if time allows, attendance with women students of color to a film or lecture related to the professor's disciplines; or starting a diversity workshop on topics in the professor's specialization that might turn into a research project or a poster for an undergraduate or graduate research exhibition that women's studies departments often organize. We were very encouraged that even in these "hard times," we could still be proactive as enlightened feminist researchers and teachers.

At the end, we thanked our panelists and scholars for their generosity. Linda Zionowski, my co-chair, worked so hard and succeeded in keeping us together and on point. It was an honor for me to work with her on the panel. We were right to count on our colleagues to bring new ideas based on their talent, consciousness, and lived experience. 